\title{
Jesenska gnojdba vinove loze i masline
}

\section{Sažetak}

Vinova loza i maslina predstavljaju dvije najvažnije drvenaste kulture u poljoprivrednoj proizvodnji u Hrvatskoj, te se uzgojem vinove loze bavi oko 40.000 proizvođača dok se uzgojem masline bavi oko 20.000 proizvođača. Kako se radi o trajnim drvenastim kulturama, jesenska gnojidba je važna radi opskrbe vinove loze i masline potrebnim hranivima za rast i razvoj u slijedećem vegetacijskom ciklusu. Važan preduvjet pravilne gnojidbe je analiza tla kako si se utvrdila plodnost tla te sastavio pravilan plan gnojidbe. Na tržištu postoje različiti oblici i formulacije gnojiva za jesensku gnojidbu vinove loze i masline.

Ključne riječi: vinova loza, maslina, jesenska gnojidba, fosfor, kalij, organska tvar

\section{Uvod}

Vinova loza i maslina predstavljaju dvije najvažnije drvenaste kulture u poljoprivrednoj proizvodnji u Hrvatskoj. Područje uzgoja masline vezano je uz primorski dio Hrvatske; od Istarskog poluotoka na sjeveru, do krajnjega juga Dalmacije, dok se vinova loza uzgaja na cijelom području Hrvatske. Prema podacima koje navodi Alpeza i sur. (2014) vinova loza uzgaja se na 20.712 ha a uzgojem vinove loze bavi se 41.000 poljoprivrednih proizvođača. Međutim, struktura proizvodnje je dosta nepovoljna, te samo 15 vinogradarskih proizvođača ima više od 100 ha vinograda, dok 5.715 vinogradara ima površine od 0,5-10 ha. Uz tako nepovoljnu strukturu proizvodnje, sam uzgoj vinove loze odvija se na vrlo različitim tipovima tala; različite plodnosti, strukture, pH vrijednosti, što predstavlja dodatnu otežavajuću okolnost u uspješnoj vinogradarskoj proizvodnji. Stoga je pravilan pristup gnojidbi vinove loze vrlo važan čimbenik za ostvarenje visokih i kvalitetnih prinosa. Slična problematika muči i proizvođače maslina. Kako navode Strikić i sur. (2012) maslina se u Hrvatskoj uzgaja na oko 17.000 ha, s oko 2.300 .000 rodnih stabala. Ukupno se uzgojem maslina bavi 21.630 poljoprivrednih gospodarstava, od čega 4.384 maslinara ima nasade veličine 1-3 ha, dok je samo 573 maslinara sa nasadim većim od 3 ha. Jednako kao i vinova loza, maslina se također uzgaja na vrlo različitim tlima, te gnojidba također predstavlja važan čimbenik za postizanje visokih i kvalitetnih prinosa ploda masline.

Stoga će u ovom radi biti prikazan niz važnih stručnih i znanstvenih spoznaja kako bi se poboljšala tehnologija gnojidbe vinove loze i masline.

\section{Važnostanalize tla za planiranjejesenske gnojidbe}

Osnovni parametar za planiranje jesenske gnojidbe je analiza tla. Kako su vinova loza i masline trajne drvenaste kulture, plodnost tla je iznimno važna. Obje kulture preko tla usvajaju većinu potrebnih hraniva, dok se preko lista, folijarnom gnojidbom vrši dopuna potrebnih količina hraniva (Fregoni 2000, Miklaužić 1989, Mirošević 1993). Analizom tla potrebno je utvrditi:

- $\mathrm{pH}$ reakciju tla

- Količinu organske tvari u tlu

- Količinu biljci pristupačnih makroelementa (najčešće fosfora i kalija)

- Količinumikroelemenata utlu

1 dr. sc. David Gluhić, Poljoprivredni odjel Poreč,Veleučilište Rijeka, Karla Huguesa 6, 52440 Poreč Autor za korespondenciju:davidgluhic@yahoo.com 
Pravo vrijeme za uzimanje uzoraka tla je nakon završetka berbe grožđa ili maslina. Ovisno o tipu tla i veličini parcele, uzorci se uzimaju za dvije dubine; 0-30 cm i 30-60 cm. Na plićim tlima, uzima se samo uzorak tla sa površinskog sloja. Na parceli se na nekoliko mjesta (najčešće „ $\mathrm{X}^{\prime \prime}$ shema uzimanja uzoraka) iz takvih pojedinačnih uzoraka sastavlja 1 prosječan uzorak tla. Za veće parcele, potrebno je napraviti 2-3 prosječna uzorka, radi bolje reprezentativnosti uzorka tla. Iz uzorka tla potrebno je odstraniti kamenje i krupnije biljne ostatke, te označeni uzorak poslatiu ovlaštenilaboratorij na analizu. Us slijedećoj tablici prikazana su-optimalne vrijednosti parametara tla za uzgoj vinove loze i masline.

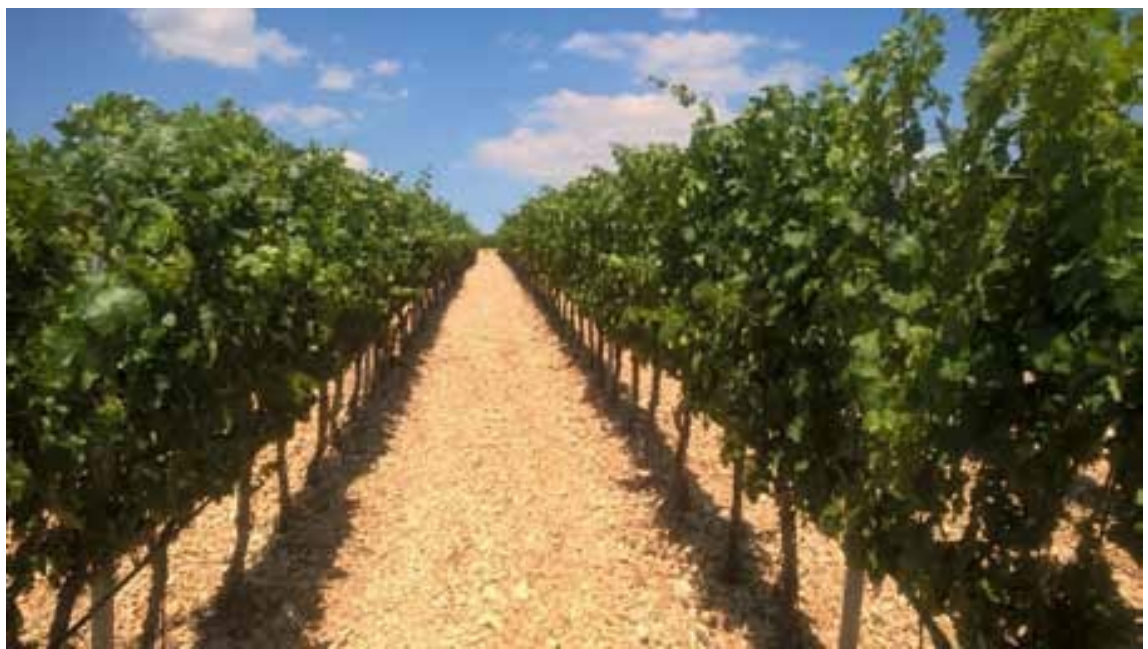

Slika 1. Vinograd na melioriranom krškom tlu srednje Dalmacije

Figure 1. Vineyard on meliorated karst soil of central Dalmatia

Tablica 1. Optimalne vrijednosti parametara tla za uzgoj vinove loze i masline (Mirošević 1993, Valli 2001)

Table 1. Optimal values of soil parameters for grapevine and olive growing (Mirošević 1993, Valli 2001)

\begin{tabular}{|c|c|}
\hline Parametar plodnosti tla/Soil parametar & Optimalna vrijednost/Optimal range \\
\hline $\mathrm{pH}$ tla (u vodi)/soil pH (water) & $6,5-7,0$ \\
\hline $\mathrm{pH}$ tla $(\mathrm{KCl}) /$ soil pH $(\mathrm{KCl})$ & $6,0-6,5$ \\
\hline Količina organske tvari (\%)/Organic matter & $1,5-3,0 \%$ \\
\hline Količini biljci pristupačnog fosfora (kao mg P O ) / & \\
\hline Phosphorus content $\quad 25$ & $10-15 \mathrm{mg} \mathrm{P}_{2} \mathrm{O}_{5} / 100$ grama tla \\
\hline $\begin{array}{l}\text { Količina biljci pristupačnog kalija ( }\left(\text { ao } \mathrm{mg} \mathrm{K}_{2} \mathrm{O}\right) / \\
\text { potassium content }\end{array}$ & $20-30 \mathrm{mg} \mathrm{K}_{2} \mathrm{O} / 100$ grama tla \\
\hline Količina ukupnih karbonata $\left(\mathrm{kao} \% \mathrm{CaCO}_{3}\right) /$ Total lime & $<10 \% \mathrm{CaCO}_{3}$ \\
\hline \multicolumn{2}{|l|}{ Mikroelementi } \\
\hline Željezo/Iron (Fe) & $50-100 \mu \mathrm{g} / \mathrm{g}$ \\
\hline Mangan/Manganese (Mn) & $20-50 \mu \mathrm{g} / \mathrm{g}$ \\
\hline Cink/Zinc (Zn) & $10-15 \mu \mathrm{g} / \mathrm{g}$ \\
\hline Bakar/Copper (Cu) & $2-5 \mu \mathrm{g} / \mathrm{g}$ \\
\hline Bor/Boron (B) & $0,5-1,0 \mu \mathrm{g} / \mathrm{g}$ \\
\hline
\end{tabular}


Za preciznije preporuke gnojidbe preporuča se napraviti detaljna analiza tla (makro i mikroelementi) koja onda čini osnovu za planiranje gnojidbe. Takva analiza se preporuča ponoviti svakih 5 godina, dok se onda nakon berbe (svake godine) provodi samo osnovna analiza tla.

Uz analizu kemijskih parametara tla, svakako se preporuča napraviti i mehaničku analizu tla (količina čestica pijeska, praha i gline) kako bi se odredio teksturni sastav tla. Naime, uz kemijske parametre, važno je poznavati i teksturni sastav tla, jer o tome ovisi dinamika i kapacitet tla za vodu u tlu (Škorić, 1982). Upravo je poznavanje dinamike vode u tlu važno za usvajanje hraniva iz tla, jer se većina hraniva iz tla usvaja vodom (posebno je to važno za dušik i kalij). Osim dinamike vode, poznavanje mehaničkog sastava tla važno je za pravilnu gnojidbu kalijem; važnog elementa za kvalitetu grožđa i randman ulja u plodovima masline. U mehanički težim tlima, gdje dominira frakcija gline, dolazi do fiksacije kalija na minerale gline, te je na takvim tlima potrebno pojačatignojidbu kalijem (Marschner 1995).

\section{Osnovni parametri kemijske analize tla}

pH vrijednost tla

Osnovni kemijski parametar tla je svakako $\mathrm{pH}$ vrijednost tla. Samo mjerenje $\mathrm{pH}$ vrijednosti je jednostavno (u vodi ili $\mathrm{KCl}-\mathrm{u}$ ) te bi svakako proizvođači trebali poznavati $\mathrm{pH}$ vrijednost tla za svoje nasade vinove loze i masline. Vinova loza i maslina su kulture koje preferiraju slabo kisela tla $(\mathrm{pH} 6,5)$ ali se pravilnom primjenom gnojiva mogu uzgajati i u tlima niže pH vrijednosti (kisela tla) ili tlima više pH vrijednosti (Fregoni 2000). Prema Škoriću (1982) tla se prema pH vrijednosti svrstavaju u slijedeće razrede (Tablica 2):

Tablica 2. Oznaka pH vrijednosti tla (Škorić, 1982)

Table 2. Soil clasification according to soil pH (Škorić, 1982)

\begin{tabular}{cc}
\hline Vrijednost pH (U vodi)/pH in soil (water) & Oznaka tla/Clasification \\
\hline$<4,5$ & Jako kisela tla/Veryacidic soil \\
\hline $4,5-5,5$ & Kisela tla/Acidic soils \\
\hline $5,5-6,5$ & Slabo kisela tla/Slightly acidic soil \\
\hline $6,5-7,2$ & Neutralna tla/Neutral soil \\
\hline$>7,2$ & Karbonatna ili alkalna tla/Carbonate or alkaline soils \\
\hline
\end{tabular}

Važnost poznavanja $\mathrm{pH}$ vrijednosti tla se pogotovo ističe u iskorištavaju osnovnih makroelemenata (N, P, K) u gnojidbi putem tla. Pri optimalnim pH vrijednostima tla (oko 6,5) usvajanje dušika, fosfora i kalija je gotovo $100 \%$, međutim padom pH vrijednosti tla, usvajanje se značajno smanjuje, kako je prikazano u slijedećoj tablici (Tablica 3):

Tablica 3. Usvajanje dušik, fosfora i kalija pri različitim pH vrijednostima tla (Omya Corporate Brochures, 2020)

Table 3. Adsorption of nitrogen, phosphorus and potassium at different soil $\mathrm{pH}$ values (Omya Corporate Brochures, 2020)

\begin{tabular}{lccccc}
\hline Vrijednost pH tla/Soil pH & 6,5 & 6,0 & 5,5 & 5,0 & 4,5 \\
\hline Dušik/Nitrogen $(\mathbf{N})$ & $100 \%$ & $89 \%$ & $77 \%$ & $43 \%$ & $30 \%$ \\
\hline Fosfor/Phosphorus $\left(\mathbf{P}_{2} \mathrm{O}_{5}\right)$ & $100 \%$ & $52 \%$ & $48 \%$ & $31 \%$ & $23 \%$ \\
\hline Kalij/Potassium $\left(\mathrm{K}_{2} \mathrm{O}\right)$ & $100 \%$ & $100 \%$ & $77 \%$ & $52 \%$ & $33 \%$ \\
\hline
\end{tabular}


Iz Tablice 3. vidljivo je da se povećanjem kiselosti tla (pH manji od 6,0) značajno smanjuje učinkovitost gnojidbe dušikom, fosforom i kalijem. Kako su dušik i kalij, važni elementi za visinu i kvalitetu prinosa vinove loze i masline, važnost korekcije $\mathrm{pH}$ vrijednosti tla, vrlo je važna mjera u popravku plodnosti tla. Najjednostavniji način popravka kiselosti tla je kacifikacija/ kalcijizacija tla; odnosno primjena vapnenog materijala na bazi kalcija ili kalcij + magnezij koji će neutralizirati višak slobodnih vodikovih $\left(\mathrm{H}^{+}\right)$iona u tlu, i time podići $\mathrm{pH}$ tla.

Količina vapnenog materijala može se utvrditi na osnovi $\mathrm{pH}$ tla, te dodatno na osnovi mjerenja hidrolitskog aciditeta tla (Škorić, 1982). Na tržištu postoje različiti vapneni materijali, koji mogu biti u obliku granula (Omya Calcipril), sitno mljevenog vapnenca ili dolomita (Holcim Agrocal granule) ili u obliku praha (Agrovapno). Za primjenu u nasadima vinove loze i masline preporuča se primjena granula zbog jednostavne primjene i lakog doziranja potrebne količine vapnenog granulata. Granule se mogu primijeniti ručno ili razbacivanjem rasipačem. Jesenski period je savršeni moment za primjenu granula, jer će se postepeno otopiti, i time mijenjati $\mathrm{pH}$ vrijednost tla. Primjena vapnenih materijala svakako bi trebala postati obavezna mjera $u$ uzgoju vinove loze i masline na kiselim tlima.

Smanjenje pH vrijednosti tla nastaje iz nekoliko razloga, od kojih su najčešći slijedeći razlozi (Goncalves da Silva i sur., 2008, Havlin i sur., 2012, Mengel i sur., 2001):

- Ispiranje kalcija $\left(\mathrm{Ca}^{2+}\right)$ iz tla viškom oborina (posebno važno za plitka i propusna tla)

- Iznošenje prinosom (kalcij je sastavni dio svake biljne stanice, te je kod visokih prinosa zna-

čajno i iznošenje kalcija iz tla)

- Primjena gnojiva koja zakiseljuju tlo (fiziološki kisela gnojiva)

- Tla nastala iz kiselih matičnih supstrata

Sam kalcij igra važnu ulogu u kvaliteti grožđa, jer se kalcij ugrađuje u staničnu stjenku svake biljne stanice. Bobice grožđa, pogotovo bijelih sorata koje imaju tanku pokožicu, uslijed nedostatka kalcija vrlo lako pucaju tijekom dozrijevanja ili kod pojave obilnih oborina, te su sklone pojavi truleži. Upravo stoga, za bijele sorte je važno poznavati pH tla i redovno vršiti korekciju kiselosti tla primjenom vapnenih materijala u jesenskog gnojidbi (Robinson, 2000).

Osim niske $\mathrm{pH}$ vrijednosti, tla mogu imati i visoke $\mathrm{pH}$ vrijednosti, te tada govorimo o karbonatnim (tlima sa viškom kalcija) ili alkaliziranim tlima (tla sa viškom klorida ili sulfata u tlu). I dok je niska pH vrijednost tla, problem za usvajanje makroelemenata (dušik, fosfor, kalij) na tlima sa visokim $\mathrm{pH}$ vrijednostima dolazi do blokade usvajanje mikroelemenata (željezo, mangan, cink, bakar, bor) (Sumner, 2000). Mikroelementi su uglavnom vezani uz različite enzimatske aktivnosti u biljci, aktivnost fotosinteze, cvatnju i oplodnji, te su također važni u gnojidbi vinove loze i masline (Romheld i Marschner, 1991).

Kod uzoraka tla, gdje je izmjeren viši pH (iznad 7,2) provodi se i analiza ukupnih karbonata u tlu; a kod tala za uzgoj vinove loze mjeri se i količina aktivnog vapna u tlu. Radi se o analitičkim metodama gdje se utvrđuju količine kalcij-karbonata u tlu, koji najviše utječe na porast pH tla. U slijedećoj tablici prikazana je klasifikacija tla prema količini ukupnih karbonata u tlu.

Tablica 4. Klasifikacija tala prema količini ukupnih karbonata u tlu (Škorić, 1982)

Table 4. Soil clasification according to total lime content (Škorić, 1982)

\begin{tabular}{lcc}
\hline Oznaka tla/Soil clasification & $\mathbf{g} / \mathbf{k g ~ t l a ~} \mathrm{CaCO}_{3}$ & $\% \mathrm{CaCO}_{3}$ \\
\hline $\begin{array}{l}\text { Nekarbonatna tla/Non-carbonate soils } \\
\text { Umjereno karbonatna tla/Moderate }\end{array}$ & $<25$ & $<2,5$ \\
\hline Karbonate soils & $20-100$ & $2,5-10,0$ \\
\hline $\begin{array}{l}\text { Jako karbonatna tla/Carbonate soils } \\
\text { Izrazito jako karbonatna tla/Extremely strong } \\
\text { carbonate soils }\end{array}$ & $100-150$ & $10,5-15,0$ \\
\hline
\end{tabular}


Zbog viška karbonatnog iona u tlima sa visokim $\mathrm{pH}$ vrijednostima dolazi do reakcije iona mikroelemenata (Fe, $\mathrm{Mn}, \mathrm{Zn}$ ) sa karbonatnim ionom i tvorbom netopivih spojeva. Isto tako, višak $\mathrm{OH}$ - iona u vodenoj otopina tla ograničava usvajanje mikroelemenata. Najčešći primjer blokade mikroelemenata u tlu je pojava kloroze na vinovoj lozi koja se uzgaja na karbonatnim tlima (Fregoni, 2000, Miklaužić, 1989). Kod masline su vizualni simptomi teže uočljivi, ali je rast i plodonošenje maslina na takvim terenima vrlo slabo. Stoga se kod uzgoja vinove loze i masline na karbonatnim tlima, često primjenjuje folijarna gnojidba mikroelementima, ili se mikroelementi dodaju u tlo oko pojedinačni stabala masline ili trsova vinove loze. Za veću učinkovitost primjene mikroelemenata u tlo, potrebno je koristiti i organska tekuća gnojiva na bazi huminskih kiselina, koji će povećati mogućnost usvajanja mikroelemenata u karbonatnim tlima (Sharma i Deb, 1988, Tisdale i sur., 1985).

Isto tako, za osnovnu gnojidbu potrebno je koristiti fiziološki kisela gnojiva; gnojiva na bazi sulfata, poput kalij-sulfata, Patent kalija i amonij-sulfata. Primjenom kiselih gnojiva, dolazi do zakiseljavanja rizosfere korijena, te se time značajno povećava usvajanje mikroelemenata u tlu (Marschner 1995).

\section{Količina raspoloživih hraniva u tlu - makroelementi}

Ovisno o tipu analize tla; poljoprivrednik dobiva podatak o količini raspoloživog fosfora i kalija u tlu (osnovna analiza tla) ili količine mikroelemenata (detaljna analiza tla). Na osnovi količine fosfora i kalija u tlu, uz poznavanje ostalih parametara tla, planiraju se količine potrebnih hraniva i gnojiva za jesensku gnojidbu. Za postizanje prosječnog prinosa od $10 \mathrm{t} / \mathrm{ha}$ grožđa, godišnje je gnojidbom potrebno u tlo unijeti $100-120 \mathrm{~kg} /$ ha dušika $(\mathrm{N}), 50-80 \mathrm{~kg} / \mathrm{ha}$ fosfora $\left(\mathrm{P}_{2} \mathrm{O}_{5}\right)$ i 85-150 kg/ha kalija ( $\left.\mathrm{K}_{2} \mathrm{O}\right)$ (Miklaužić 1989). Za preciznije doziranje gnojiva, u gnojidbi vinove loze, vinogradari se mogu poslužiti slijedećom tablicom gdje su prikazane količine hraniva koje vinova loza troši za postizanje određenog uroda grožđa (Tablica 5). Podaci iz ove tablice su naročito važni za procjenu potrošenih hraniva tijekom jedne vegetacijske godine prinosom ploda.

Tablica 5. Utrošak osnovnih hraniva za različite prinose kod uzgoja vinove loze i masline (Valli, 2001)

Table 5. Consumption of basic nutrients for different yields of vinegrapes and olives (Valli, 2001)

\begin{tabular}{|c|c|c|c|c|}
\hline Kultura/Plant & $\begin{array}{l}\text { Količina kg hraniva za } \\
1 \text { tonu prinosa ploda/ }\end{array}$ & Dušik/Nitrogen (N) & $\begin{array}{c}\text { Fosfor/Phosphorus } \\
\left(\mathrm{P}_{2} \mathrm{O}_{5}\right)\end{array}$ & $\begin{array}{c}\text { Kalij/Potassium } \\
\left(\mathrm{K}_{2} \mathrm{O}\right)\end{array}$ \\
\hline Vinova loza & The amount of $\mathrm{kg}$ of & $2,7-3,3$ & $0,6-0,7$ & $3,0-3,8$ \\
\hline Maslina & fruit yield & $8,0-10,0$ & $2,3-3,5$ & $17,5-19,6$ \\
\hline
\end{tabular}

Podaci iz ove tablice su naročito važni za procjenu potrošenih hraniva tijekom jedne vegetacijske godine prinosom ploda, te zajedno sa rezultatima analize tla, čine osnovu za planiranje jesenske gnojidbe vinove loze i masline.

U slijedeće dvije tablice (Tablica 6 i 7) prikazana je optimalna količina za biljci pristupačan fosfor ( $\left(\right.$ aoo $\mathrm{P}_{2} \mathrm{O}_{5}$ ) i kalij ( $\left(\mathrm{kao} \mathrm{K}_{2} \mathrm{O}\right.$ ) za analizu gdje se kao sredstvo za ekstrakciju koristi amonij-laktat otopina (tzv. AL metoda) koja se najčešće koristi u laboratorijima u Hrvatskoj (Škorić, 1982). 
Tablica 6. Klasifikacija tla prema količina fosfora ( $m g \mathrm{P}_{2} \mathrm{O}_{5} / 100$ grama tla) u tlu za uzgoj poljoprivrednihkultura(Škorić, 1982)

Table 6. Soil clasification according to phosphorus content (Škorić, 1982)

\begin{tabular}{lc}
\hline $\begin{array}{l}\text { Oznakaopskrbljenostitla/ } \\
\text { Identification of soil supply }\end{array}$ & $\begin{array}{c}\text { Količina fosfora u flu/ } \\
\text { The amount of phosphorus in the soil } \\
\text { (kao } \mathrm{mg}_{2} \mathrm{O}_{5} / 100 \text { grama tla) }\end{array}$ \\
\hline Vrlo siromašno tlo/Very poor soil & $<10$ \\
\hline Siromašno tlo/Poor soil & $10-15$ \\
\hline Dobro opskrbljeno tlo/Well stocked ground & $15-30$ \\
\hline Vrlo dobro/Very good & $30-45$ \\
\hline
\end{tabular}

Tablica 7. Klasifikacija tla prema količini kalija (mg $\mathrm{K}_{2} \mathrm{O} / 100$ grama tla) u tlu za uzgoj poljoprivrednih kultura (Škorić, 1982)

Table 7. Soil clasification according to potasium content (Škorić, 1982)

\begin{tabular}{cccc}
\hline $\begin{array}{c}\text { Opskrbljenosttla/ } \\
\text { Soil sunnolv }\end{array}$ & Laganotlo/Lightsoil & $\begin{array}{c}\text { Srednje teško tlo/ } \\
\text { Medium heavysoil }\end{array}$ & $\begin{array}{c}\text { Teška(glinovita) tla/ } \\
\text { Heavy (clay) soil }\end{array}$ \\
\hline $\begin{array}{c}\text { Vrio siromásno tlo/ } \\
\text { Very poor soil }\end{array}$ & $<12$ & $<15$ & $<20$ \\
\hline $\begin{array}{c}\text { Siromašno tlo/ } \\
\text { Poor soil }\end{array}$ & $12-20$ & $15-25$ & $20-30$ \\
\hline $\begin{array}{c}\text { Osrednjetlo/ } \\
\text { Moderately soil } \\
\text { Dobro/Good }\end{array}$ & $20-35$ & $25-40$ & $30-45$ \\
\hline $\begin{array}{c}\text { Vrlodobro/ } \\
\text { Vorygood }\end{array}$ & $35-45$ & $40-50$ & $45-60$ \\
\hline & $>45$ & $>50$ & $>60$ \\
\hline
\end{tabular}

\section{Količina raspoloživih hraniva u tlu - mikroelementi}

Detaljnom analizom tla, mjeri se i količina mikroelementa u tlu. Radi se o važnom dijelu plodonosti tla, jer i mikroelementi poput prije spomenutim makroelemenata također igraju važnu ulogu u rastu i razvoju vinove loze i masline (Basar i Gurel, 2016, Bhardwaj i Omanwar 1994, Connell i Vossen, 2007, Fregoni 2000, Perica i sur., 2002). Razlika je samo u količinama, koje su biljkama potrebne, pa je stoga potrošnja mikroelemenata značajno manja u odnosu na potrošnju makroelemenata. U ovoj grupi nalaze se slijedeći hranivi elementi; željezo (Fe), mangan (Mn), cink (Zn), bakar (Cu), molibden (Mo) i bor (B).

Nepovoljni čimbenici koji ograničavaju usvajanje mikroelemenata iz tla su visoka pH vrijednost te visoka količina karbonata ili drugih alkalija u tlu (Mengel i sur., 2001, Romheld i Marschenr 1991, Tagliavini i Rombola, 2001).

\section{Količina organske tvari u tlu}

Organska tvar u tlu igra vrlo važnu ulogu u plodnosti tla, jer pozitivno utječe na niz kemijskih i fizikalnih parametara u tlu. Jednako tako, organska tvar u tlu vrlo je važna za mikrobiološku aktivnost tla te ima i značajnu ekološku ulogu (Altomare i Tringovska, 2011, Bulluck i sur., 2002, Chen 2006, Mengel i sur., 2001). To posebno dolazi do izražaja u intenzivnoj vinogradarskoj proizvodnji gdje je česta upotreba mehanizacije i različitih kemijskih preparata (fungicidi, insekticidi, herbicidi) koji nepovoljno utječu na mikrobiološku aktivnost tla. Optimalna količina organske tvari u tlu za uzgoj vinove loze i masline kreće se oko 3\%. U tablici 8. prikazana je ocjena humoznosti tla prema količini humusa u tlu (Škorić, 1982). 
Tablica 8. Oznaka humoznosti tla prema sadržaju humusa (Škorić, 1982)

Table 8. Soil clasification according to humus content (Škorić, 1982)

\begin{tabular}{cc}
\hline Sadržaj humusa/Humus & Oznaka humoznosti/Soil clasification \\
\hline$<1 \%$ & Vrlo slabo humozna tla/Very poorly humus soil \\
\hline $1-3 \%$ & Slabo humozna tla/Poorly humus soil \\
\hline $3-5 \%$ & Humozna tla/Humorous soil \\
\hline $5-10 \%$ & Jako humozna tla/Very humus soil \\
\hline$>10 \%$ & Vrlo jako humozna tla/Very very humus soil \\
\hline
\end{tabular}

Tla sa dovoljnom količinom organske tvari dobro zadržavaju vodu, imaju povoljne vodozračne odnose te su dobre plodnosti. Međutim, u intenzivnom uzgoju vinove loze i masline, često dolazi do nedovoljne količine organske tvari u tlu, iz nekoliko razloga (Winkler i sur., 1974):

- Izostanak organske gnojidbe u nasadima vinove loze i masline

- Iznošenje ostataka rezidbe iz nasada

- Tla koja su nastala iz supstrata koji sadržavaju malo organske tvari (vrlo čest slučaj kod pripreme tla u primorskom dijelu Hrvatske gdje se melioracijama krša stvaraju supstrati za nove nasade vinove loze i masline)

- „Stara“ poljoprivredna tla gdje je uzgoj vinove loze i masline već niz stoljeća, te je stvaranje nove organske tvari vrlo malo.

Za povećanje količine organske tvari postoji više tehnoloških mogućnosti. lako se u literaturi često spominje primjena zrelog stajskog gnoja, danas zbog vrlo limitiranog stočnog fonda i novog načina uzgoja stoke bez stelje, dostupnost kvalitetnog stajskog gnoja je vrlo ograničena. Stoga se vinogradari i maslinari okreću novih proizvodima na tržištu. Tako se danas za organsku gnojidbu vinograda i masline koriste:

- Peletirani stajski gnoj goveda, konja, ovaca, svinja ili peradi

- U intenzivnim nasadima gdje postoji sustavi za fertirigaciju primjenjuju se tekuća organska gnojiva na bazi huminskih kiselina.

Zbog niza pozitivnih svojstava (oblik peleta, nizak sadržaj vode, visoka količina organske tvari, laka primjena i dr.) dominantno se koriste peletirana stajska gnojiva. Na tržištu postoji veliki broj proizvoda, kako za ekološku tako i konvencionalni uzgoj vinove loze i masline. Prosječna doza primjene je 1-3 t/ha ovisno o tipu gnojiva. Kako peletirana stajska gnojiva na bazi gnojiva peradi i svinjskog gnoja brzo mineraliziraju u tlu, za primjenu u vinogradima i maslinicima preporuča se primjena peletiranih stajskih gnojiva na bazi gnojiva goveda i konja.

Osim klasičnih peletiranih organskih gnojiva, na tržištu se nalaze i organsko-mineralna gnojiva, gdje je spajanjem dviju tehnologija (organska gnojiva + mineralna gnojiva) dobiven kompletniji i kvalitetniji proizvod za gnojidbu vinove loze i masline. Organsko-mineralna gnojiva, donose prednosti dviju tehnologija (visoka količina organske tvari i visoka količina hraniva) u jednostavnoj i učinkovitoj primjeni. Mogu se primjenjivati ručnim ili strojnim razbacivanjem (rasipačima) te na tržište dolaze u malim pakiranjima ( 25 ili $30 \mathrm{~kg}$ ) ili velikim pakiranjima (600 ili $1.000 \mathrm{~kg}$ ), te se tima otvara mogućnost primjene kod poljoprivrednih proizvođača različitih veličina nasada. I dok su prije samo nekoliko godina ovo bili novi proizvodi na tržištu; danas takva gnojiva zauzimaju značajan udio na tržištu, te njihova upotreba raste iz godine u godinu. Postoji veliki broj različitih formulacija na tržištu, pa se vrlo lako može izabrati prikladna formulacija za primjenu u nasadu, te se većina može koristiti i u ekološkoj poljoprivrednoj proizvodnji. U slijedećoj tablici prikazan je dio organsko-mineralnih gnojiva dostupnih na tržištu Hrvatske. 


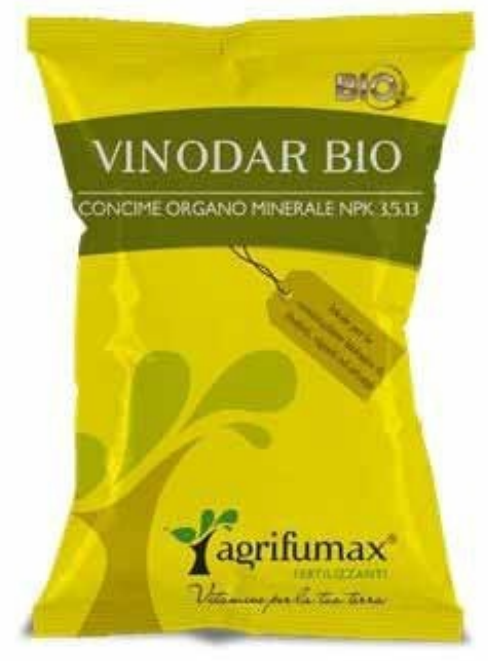

Slika 2. Organsko-mineralno gnojivo Vinodar BIO NPK 3:5:13 za jesensku gnojidbu konvencionalnih i ekoloških nasada vinove loze i masline (proizvođač Agrifumax, Italija)

Figure 2. Organic-mineral fertilizer Vinodar BIO NPK 3: 5: 13 for autumn fertilization of conventional and ecological vineyards and olive groves (producer Agrifumax, Italy)

\section{Tehnologijajesenske gnojidbe vinove loze i masline}

$\mathrm{U}$ jesenskoj gnojidbi gnojiva se primjenjuju u:

- Gnojidbi u tlo

- Folijarnoj gnojidbi

Gnojidba u tlo je glavni način primjene gnojiva u jesenskoj gnojidbi. Iz vrlo jednostavnog razloga; jer je cilj jesenske gnojidbe stvaranje dovoljne zalihe hraniva za slijedeći vegetacijski ciklus. Ovisno o klimatskim uvjetima i veličini proizvodnih nasada vinove loze i masline, provodi se od završetka berbe te kroz cijeli jesensko-zimski period. Glavni način primjene je rasipanje po površini tla, te ukoliko postoje mogućnosti zaoravanje ili plitko unošenje u tlo. Na taj način se gnojiva u tlo puno brže aktiviranju, te se vežu na minerale gline ili organsku tvar u tlu. Kako tijekom jesensko-zimskog perioda često ima obilnih kiša, ne preporuča se ostavljanje gnojiva na površini tla, jer uslijed jakih oborina može doći do odnošenja gnojiva sa površine tla. Problem je međutim na plitkim, kamenitim tlima, gdje nije moguće unošenje gnojiva u tlo, te često tijekom jesensko-zimskog perioda dolazi do ispiranja gnojiva uslijed jačih oborina.

Prijašnjih godina, pogotovo u vinogradarskoj proizvodnji, često se vršilo deponiranje gnojiva u međuredni prostor, primjenom posebnih podrivača. To se koristilo za primjenu granuliranih mineralnih gnojiva. Sama tehnologija gnojidbe primjenom deponatora ima ograničeni učinak, jer se višegodišnjom primjenom stvara zona visoke koncentracije hraniva na istoj dubini, dok je migracija hraniva iz zone deponiranja, pogotovo fosfora, vrlo slaba. Fosfor je element vrlo slabe pokretljivosti u tlu, te se iz tog razloga polako napušta tehnologija deponiranja gnojiva, te se gnojiva ponovo sve češće razbacuju površinski u zonu ispod trsa/stabla masline ili po cijeloj površini, te se potom plitko unose u tlo.

Primjena folijarnih gnojiva na bazi mikroelemenata i biostimulatora na bazi ekstrakta morskih algi novija je tehnologija u jesenskoj gnojidbi vinove loze i masline. Primjena mikroelemenata u nasadima vinove loze provodi se nakon završetka berbe a prije početka pada lista (Robinson 2000). Ukoliko su mjere zaštite od bolesti redovno primijenjene tijekom vegetacije vinove loze, tada u vinogradu ima aktivne lisne mase koja može usvojiti hraniva. Nakon berbe grožđa počinje priprema vinove loze za zimsko mirovanje, te biljka prebacuje sva dostupna hraniva iz lista u trajne organe (trs, korijen), te se time može usvojiti i značajna količina mikroe- 
lemenata, koji se, „deponiraju“ u trsu za slijedeću vegetaciju. Iz istog razloga, pogotovo u vinogradima slabije kondicije, primjenjuju se i biostimulatori na bazi ekstrakta morske alge. Radi se o posebnoj grupi biostimulatora, koji su vrlo bogati fiziološki bioaktivnim sastojcima (prirodni hormoni, polisaharidi, vitamini, alginati i dr.) koji imaju vrlo dobar učinak na rast i razvoj vinove loze u slijedećoj vegetaciji.

Sličan učinak ima i folijarna primjena mikroelemenata u maslinama nakon završetka berbe (Therios 2009, Rodrigues i sur., 2012, Turan i sur., 2013). lako se maslina bere značajno kasnije od vinove loze, temperature u primorskom dijelu Hrvatske su još uvijek povoljne, te se nakon berbe mogu primijeniti folijarna gnojiva na bazi mikroelemenata.

Osim klasičnih gnojiva na bazi mikroelemenata, u maslinarstvu je posebno dobar učinak pokazala primjena gnojiva na bazi bakrenog glukonata (Cu-glukonat). Radi se o posebno formuliranoj molekuli bakra (veza bakra na glukonsku kiselinu), koja ima sistemični učinak (ulazi u list i otporna je na ispiranje kišom) i koja pokazuje snažan preventivan učinak na razvoj bolesti paunovo oko (Therios 2009). Za razliku od ostalih anorganskih oblika bakra, Cu-glukonat nema fitotoksični učinak pri nižim temperaturama zraka te ne izaziva defolijaciju lista masline.

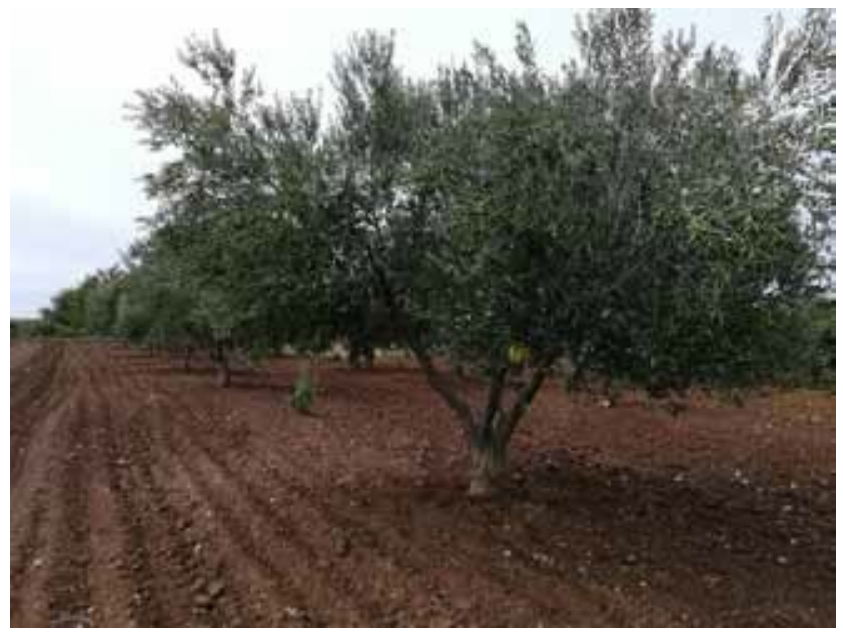

Slika 3. Nasad masline na crvenici, tipičnom mediteranskom tlu

Figure 3. Olive grove on red soil, typical Mediterranean soil

Izbor gnojiva za jesensku gnojidbu vinove loze i masline

Za jesensku gnojidbu vinove loze i masline na tržištu je dostupan veliki broj različitih gnojiva; tako da se pravilnim izborom mogu zadovoljiti potrebe za različite agroekološke uvjete.

Mineralna gnojiva

U segmentu mineralnih gnojiva, dostupna su kompleksna mineralna gnojiva (različite NPK formulacije) koja se najčešće koriste. Osim kompleksnih, mogu se koristiti i jeftinija, miješana gnojiva te pojedinačna mineralna gnojiva. Kod primjene mineralnih gnojiva naglasak $u$ jesenskoj gnojidbi je na fosforu i kaliju, te je potrebno voditi računa o obliku kalija. Gnojiva na bazi kalij-sulfata su fiziološki kisela te se primjenjuju na neutralnim i karbonatnim tlima, pogotovo kod vinove loze, dok su gnojiva na bazi kalij-klorida, fiziološki alkalna i primjenjuju se na kiselim tlima. Kratak pregled mineralnih gnojiva prikazan je u slijedećoj tablici. 
Tablica 9. Prikaz mineralnih gnojiva za jesensku gnojidbu vinove loze i masline (prema podacima zastupnika za hrvatsko tržište za 2020. godinu)

Table 9. Mineral fertilizers for autumn fertilization of grapevines and olives (partial data from fertilizer traders of Croatian market, year 2020)

\begin{tabular}{|c|c|c|}
\hline $\begin{array}{l}\text { Tip gnojiva/ } \\
\text { Fertilizer type }\end{array}$ & $\begin{array}{c}\text { Preporučena doza/ } \\
\text { Dosage }\end{array}$ & $\begin{array}{l}\text { Dodatnanapomena/ } \\
\text { Note }\end{array}$ \\
\hline \multicolumn{3}{|l|}{$\begin{array}{l}\text { Kompleksna mineralna } \\
\text { gnojiva/ Complex mineral } \\
\text { fertilizers }\end{array}$} \\
\hline NPK 7:20:30 & $400-800 \mathrm{~kg} / \mathrm{ha}$ & $\begin{array}{l}\text { Gnojivo s kalijem u obliku kalij-klorida. Za kisela tla } \\
\text { Potassium fertilizer in the form of potassium chloride. For } \\
\text { acidic soils / }\end{array}$ \\
\hline NPK 5:20:30S & $400-800 \mathrm{~kg} / \mathrm{ha}$ & $\begin{array}{l}\text { Gnojivo sa kalijem u obliku kalij-sulfata. Za karbonatna tla/ } \\
\text { Potassium fertilizer in the form of potassium sulfate. For } \\
\text { carbonate soils }\end{array}$ \\
\hline PK 20:30 & $400-800 \mathrm{~kg} / \mathrm{ha}$ & $\begin{array}{l}\text { Kompleksno gnojivo bez dušika. Kalij u obliku klorida/ } \\
\text { Nitrogen-free complex fertilizer. Potassium in the form of } \\
\text { chloride }\end{array}$ \\
\hline \multicolumn{3}{|l|}{$\begin{array}{l}\text { Mješana gnojiva/ Mixed } \\
\text { fertilizer }\end{array}$} \\
\hline PK 15:30 & $600-1.000 \mathrm{~kg} / \mathrm{ha}$ & $\begin{array}{l}\text { Miješano gnojivo. Jeftinija alternativa za kompleksna } \\
\text { gnojiva. Gnojivo sa pojedinačnim granulama koja sadrže } \\
\text { samo fosfori samo kalij/ Mixed fertilizer. Cheaper alternative } \\
\text { to complex fertilizers. Fertilizer with individual granules } \\
\text { containing only phosphorus and only potassium }\end{array}$ \\
\hline \multicolumn{3}{|l|}{$\begin{array}{l}\text { Jednokomponentna gnojiva/ } \\
\text { One-component fertilizers }\end{array}$} \\
\hline $\begin{array}{l}\text { 1.6\% Superfosfat(tzy. } \\
\text { "jednostruki" superfosfat)/ } \\
\text { Superphosphate (so-called } \\
\text { "single" superphosphate) }\end{array}$ & $600-1.500 \mathrm{~kg} / \mathrm{ha}$ & $\begin{array}{l}\text { Gnojivo samo na bazi fosfora. Za primjenu na tlima sa } \\
\text { niskom količinom fosfora/ Phosphorus-based fertilizer only. } \\
\text { For use on soils with low phosphorus }\end{array}$ \\
\hline $\begin{array}{l}\text { 46\% Superfosfat(tzv. } \\
\text { „trostruki superfosfat)/ } \\
\text { Superphosphate (so-called } \\
\text { "triple" superphosphate) }\end{array}$ & $300-600 \mathrm{~kg} / \mathrm{ha}$ & $\begin{array}{l}\text { Gnojivo sa visokom koncentracijom fosfora. Za primjenu na } \\
\text { tlima sa vrlo niskom količinom fosfora/ Fertilizer with high } \\
\text { phosphorus concentration. For application on soils with a } \\
\text { very low amount of phosphorus }\end{array}$ \\
\hline $\begin{array}{l}50 \% \text { Kalij-sulfat/ Potassium } \\
\text { sulfate }\end{array}$ & $500-1.000 \mathrm{~kg} / \mathrm{ha}$ & $\begin{array}{l}\text { Gnojivo na bazi kalij-sulfata. Za primjenu na tlima sa niskom } \\
\text { količinom kalija. Fiziološki kiselo gnojivo./ Potassium } \\
\text { sulphate fertilizer. For application on soils with low } \\
\text { potassium content. Physiological acid fertilizer. }\end{array}$ \\
\hline $\begin{array}{l}60 \% \text { Kalij-klorid/ Potassium } \\
\text { chloride }\end{array}$ & $500-1.000 \mathrm{~kg} / \mathrm{ha}$ & $\begin{array}{l}\text { Gnojivo na bazi kalij-sulfata. Za primjenu na tlima sa niskom } \\
\text { količinom kalija. Fiziološki alkalno gnojivo./ Potassium } \\
\text { sulphate fertilizer. For application on soils with low } \\
\text { potassium content. Physiological alkaline fertilizer. }\end{array}$ \\
\hline
\end{tabular}

\section{Organska gnojiva}

Za jesensku primjenu organskih gnojiva, vinogradarima i maslinarima ostaju na raspolaganju nekoliko mogućnosti; stajski gnoj (različitog sastava i kvalitete), peletirani stajski gnoj (deklarirani sastav i kvaliteta), vermikompost (glisnjak) i tekuća organska gnojiva. Zbog ograničene dostupnosti stajskog gnoja, najčešći izbor su peletirana stajska gnojiva. Na tržištu postoje različiti proizvođači, te je izbor peletiranih stajskih gnojiva velik. Za gnojidbu vinove loze i masline, trebalo bi birati peletirana gnojiva na bazi stajskog gnoja goveda i konja, koji su najbolje kvalitete. S druge strane svakako treba izbjegavati peletirana gnojiva na bazi stajskog gnoja peradi i svinja. Prosječna doza primjene peletiranih organskih gnojiva je $1.000-1.500 \mathrm{~kg} / \mathrm{ha}$, ovisno o količini humusa u tlu.

lako neki poljoprivrednici imaju naviku primjene ostatka komine grožđa i prerade masline koristiti direktno kao organsku gnojidbu nasada, to nije preporučljivo. Naime, radi se o organ- 
skom materijalu vrlo loših karakteristika, koji bi prije primjene u vinogradima i maslinicima morao proći kontrolirani proces kompostiranja. Tek pravilno kompostirani ostaci komine grožđa i prerade maslina mogu se koristiti u gnojidbi trajnih nasada.

Osim peletiranih gnojiva, postoji i mogućnost primjene tekućih organskih gnojiva u jesenskoj gnojidbi trajnih nasada. Takva gnojiva primjenjuju se prskanjem po površini tla ili kroz sustav fertirigacije. Kako se radi o proizvodima na huminskih ili fulvo kiselina, dobro se vežu u tlu, učinak im je brz i povoljno djeluju na kemijska i fizikalna svojstva tla. Prosječna doza primjene takvih gnojiva je 20-40 lit/ha ovisno o koncentraciji huminskih i fulvo kiselina. Osnovne karakteristike tekućih organskih gnojiva prikazane su u slijedećoj tablici.

Tablica 10. Osnovne karakteristike tekućih organskih gnojiva za jesensku gnojidbu vinove loze i maslina (prema podacima zastupnika za hrvatsko tržište za 2020. godinu)

Table 10. Liquid organic fertilizers for autumn fertilization of grapevines and olives (partial data from fertilizer traders of Croatian market, year 2020)

\begin{tabular}{|c|c|c|c|}
\hline $\begin{array}{l}\text { Trgovačkinaziv gnojiva/ } \\
\text { Fertiliazer name }\end{array}$ & Proizvođač/Producer & Sastav/Content & Doza primjene/Dosage \\
\hline $\begin{array}{l}\text { Humistar } \\
\text { (tekuće organsko gnojivo na } \\
\text { bazi američkog leonardita/ } \\
\text { liquid organic fertilizer based } \\
\text { on American leonardite) }\end{array}$ & $\begin{array}{l}\text { Tradecorp, Španjolska/ } \\
\text { Spain }\end{array}$ & $\begin{array}{l}\text { 12,0\% huminske kiseline/ } \\
\text { humic acid } \\
\text { 3,0\% fulvokiseline/ fulvic } \\
\text { acid }\end{array}$ & $\begin{array}{l}20-40 \text { lit/ha } \\
50-150 \text { ml po stablu } \\
\text { masline (ovisno o starosti } \\
\text { stabla masline)/ per olive } \\
\text { tree (depending on the } \\
\text { age of the olive tree) }\end{array}$ \\
\hline $\begin{array}{l}\text { Idai Fertireg } \\
\text { (gnojivo proizvedeno } \\
\text { sukladno EZ normi } 834 / 2007 \\
\text { za primjenu u ekološkoj } \\
\text { poljoprivredi/ fertilizer } \\
\text { produced in accordance with } \\
\text { EUstandard834/2007for use } \\
\text { in organic farming) }\end{array}$ & $\begin{array}{l}\text { Idai Nature, Španjolska/ } \\
\text { Spain }\end{array}$ & $\begin{array}{l}\text { 35\% huminskog ekstrakta } \\
\text { (huminskih i fulvo } \\
\text { kiselina)/ humic extract } \\
\text { (humic and fulvic acids) }\end{array}$ & $\begin{array}{l}20-40 \text { lit/ha } \\
50-150 \mathrm{ml} \text { po stablu } \\
\text { masline (ovisno o starosti } \\
\text { stabla masline)/per olive } \\
\text { tree (depending on the } \\
\text { age of the olive tree) }\end{array}$ \\
\hline Agriumic & $\begin{array}{l}\text { Chimica D'Agostino, } \\
\text { Italija/Italy }\end{array}$ & $\begin{array}{l}12,0 \% \text { huminske kiseline/ } \\
\text { humic acid }\end{array}$ & 15-20 lit/ha \\
\hline
\end{tabular}

\section{Organsko-mineralna gnojiva}

Ovo je kategorija gnojiva koja se najviše preporuča za jesensku gnojidbu vinove loze i maslina. Radi se o novim oblicima gnojiva, gdje se spajaju pozitivne strane iz dvije postojeće kategorije gnojiva; organska gnojiva kao izvor organske tvari i mineralna gnojiva kao izvor hraniva. lako sadrže manje količine NPK hraniva u odnosu na čista mineralna gnojiva učinak u gnojidbi je vrlo dobar. Kako su NPK hraniva vezana na organsku komponentu, takva gnojiva nisu podložna ispiranju te je učinak gnojidbe znatno duži. To je izrazito važno za trajne nasade, poput vinove loze i masline, gdje biljke imaju potrebu za hranivima kroz cijeli vegetacijski ciklus. Doze primjene ovise o koncentraciji NPK hraniva, i prosječno se primjenjuju u količini od 600-800 kg/ ha. Za vinogradare i maslinare koji su u sustavu ekološke poljoprivredne proizvodnje, postoje organsko-mineralna gnojiva koja posjeduju certifikat za primjenu u ekološkoj poljoprivredi.

$\mathrm{Na}$ tržištu je dostupan veliki broj različitih formulacija organsko-mineralnih gnojiva. Za jesensku gnojidbu svakako treba birati formulacije koje sadrže više količine fosfora i kalija. U slijedećoj tablici prikazan dio gnojiva dostupan na tržištu Hrvatske. 
Tablica 11. Prikaz organsko-mineralnih gnojiva za jesensku gnojidbu vinove loze i masline (prema podacima zastupnika za hrvatsko tržište za 2020. godinu)

Table 11. Organic-mineral fertilizers for autumn fertilization of grapevines and olives (partial data from fertilizer traders of Croatian market, year 2020)

\begin{tabular}{lll}
\hline Trgovačkinaziv gnojiva/Fertililazer name & Proizvođač/Producer & Doza primjene/Dosage \\
\hline Vinodar BIO NPK 3:5:13 & Agrifumax, Italija/Italy & $600-800 \mathrm{~kg} / \mathrm{ha}$ \\
\hline Bioprimus NP 5:7 & Agrifumax, Italija/Italy & $600-800 \mathrm{~kg} / \mathrm{ha}$ \\
\hline TerraPlus NP 10:22 & Compo, Njemačka/Germany & $200-400 \mathrm{~kg} / \mathrm{Ha}$ \\
\hline Superguanoxy NPK 4:10:5 & Fomet, Italija/Italy & $700-1.000 \mathrm{~kg} / \mathrm{ha}$ \\
\hline Proeco NPK 5:10:10 & Ilsa, Italija/Italy & $500-700 \mathrm{~kg} / \mathrm{ha}$ \\
\hline Greena Biobase NPK 3:8:8 & Greena, Italija/Italy & $700-1.000 \mathrm{~kg} / \mathrm{ha}$ \\
\hline
\end{tabular}

\section{Gnojiva na bazi mikroelemenata}

Gnojiva na bazi mikroelemenata uglavnom se primjenjuju folijarno, ali se isto tako mogu primijeniti kroz sustav fertirigacije ili miješanjem sa mineralnim ili organskim gnojivima. Odluka o primjeni mikroelemenata treba se bazirati na rezultatima analize tla (pogotovo ako je neki od mikroelemenata u značajnom nedostatku) te na stanju nasada. Najčešće se primjenjuju mješavine mikroelemenata ili gnojiva koja sadrže samo pojedini mikroelement. Za jesensku folijarnu primjenu preporuča se isključivo primjena mikroelemenata $u$ helatnom obliku, jer se zbog promjene klimatskih uvjeta (niže temperature zraka, kraći dan, manji intenzitet fotosinteze) intenzitet usvajanja mikroelemenata preko lista značajno smanjuje (Mengel i sur., 2001). Ostali, jeftiniji oblici gnojiva poput mikroelemenata u obliku sulfata, vrlo se slabo usvajaju u takvim uvjetima te je njihova učinkovitost u jesenskoj folijarnoj gnojidbi vrlo slaba. Osim gnojiva koji sadrže samo jedno hranivo, za jesensku folijarnu gnojidbu dobar učinak su pokazala gnojiva koja sadrže više elemenata, jer se time uspješno rješava potreba vinove loze i masline za mikroelementima.

Tablica 12. Sastav gnojiva Cocktail Jade (proizvođač Tradecorp, Španjolska) za jesensku folijarnu gnojidbu vinove loze i masline (gnojivo sa EcoCert certifikatom za ekološku poljoprivrednuproizvodnju)

Table 12. Composition of fertilizer Cocktail Jade (Tradecorp, Spain) for autumn foliar fertilization of grapevines and olives (with EcoCert certificate for organic agriculture)

\begin{tabular}{lc}
\hline Hranivielement/Element & Količina/Quantity \\
\hline Mikroelementi/Microelements: & \\
\hline Željezo/Iron (Fe-EDTA helat) & $4,0 \%$ \\
\hline Mangan/Manganese (Mn-EDTA helat) & $4,0 \%$ \\
\hline Cink/Zinc (Zn-EDTA helat) & $0,8 \%$ \\
\hline Bor/Boron (B) & $1,5 \%$ \\
\hline Makroelementi/Macroelements: & $5,1 \%$ \\
\hline Magnezij/Magnesium (MgO) & $10,0 \%$ \\
\hline Sumpor/Sulfur ( $\left.\mathrm{SO}_{3}\right)$ & \\
\hline
\end{tabular}


Poseban dio tehnologije primjene mikroelemenata je primjena Cu-glukonata kod maslina. Radi se o posebno formuliranim gnojivima gdje je molekula bakra vezana na glukonsku kiselinu, te stoga ima sistemični učinak, brzo ulazi u list i nema fitotoksični učinak na lisnu masu zbog niske temperature zraka i vlage. Izbor takvih gnojiva je vrlo limitiran na tržištu, zbog specifične proizvodnje takvih gnojiva. lako dio trgovaca na tržištu nudi gotove mješavine bakrenih gnojiva sa aminokiselinama, takva gnojiva nemaju učinak poput gnojiva na bazi Cu-glukonata.

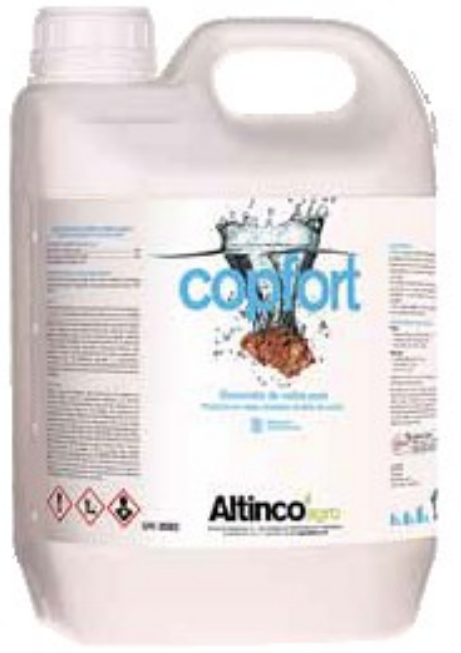

Slika 4. Gnojivo Copfort na bazi Cu-glukonata za jesensku folijarnu gnojidbu maslina nakon berbe (proizvođač Altinco, Španjolska)

Figure 4. Copfort fertilizer based on Cu-gluconate for autumn foliar fertilization of olives after harvest (producer Altinco, Spain)

\section{Zaključak}

Jesenska gnojidba predstavlja važnu tehnološku mjeru u uzgoju vinove loze i masline, jer su vinova loza i maslina trajne drvenaste kulture, koje imaju visoke zahtjeve za hranivima u tlu tijekom cijelog vegetacijskog razdoblja. Razvojem tehnologije proizvodnje gnojiva poljoprivrednicima su na raspolaganju različiti oblici i formulacije gnojiva (mineralna, organsko-mineralna, organska, gnojiva na bazi mikroelemenata). Važan preduvjet jesenske gnojidbe je i analiza tla, kojom će se utvrditi stanje plodnosti tla, i prema tome složiti kvalitetan plan jesenske gnojidbe vinove loze i masline

\section{Literatura}

Alpeza I., Prša I., Mihaljević B. (2014) Vinogradarstvo i vinarstvo Republike Hrvatske u okviru svijeta, Glasnik zaštite bilja 37 (4): 6-13.

Altomare, C., I. Tringovska. (2011) Benefi soil microorganisms, an ecological alternative for soil fertility management. Sustainable Agriculture Reviews 7:161-214.

Başar H, S. Gürel (2016) Effects of Soil and Foliar Treatments of Alone and Combined Applications of Boron with Iron and Zinc on Boron, Zinc, and Iron Contents of Gemlik Olive Trees, Communications in Soil Science and Plant Analysis, 47:9

Bhardwaj, V., P. K. Omanwar (1994) Long-term effects of continuous rotational cropping and fertilization on crop yields and soil properties, II: Effects on EC, pH, organic matter, and available nutrients of soil. Journal of the Indian Society of Soil Science 42:387-392

Bulluck, I. R., M. Brosius, G. K. Evanylo, J. B. Ristaino. (2002) Organic and synthetic fertility amendments infl es soil microbial physical and chemical properties on organic and conventional farms. Applied Soil Ecology 19 (2):147-60

Chen J.H. (2006) The combined use of chemical and organic fertilizers and/or biofertilizer for crop growth and soil fertility. Proceedings of International Workshop on Sustained Management of the Soil-Rhizosphere System for Effi t Crop Production and Fertilizer Use

Connell, J. H., P. M. Vossen (2007) Organic olive orchard nutrition. In Organic olive production manual, ed. P. M. Vossen, 37-43. Oakland, CA: University of California

Fageria, N. K., M. P. Barbosa-Filho, A. Moreira, C. M. Guimaraes (2009) Foliar fertilization of crop plants. Journal of Plant Nutrition 32:1044-1064 
Fregoni M. (2000) Viticoltura di qualita, Informatore agrario, Italy

Gonçalves da Silva M.A. , Marcos Antonio Pavan, Antonio Saraiva Muniz, Telmo Antonio Tonin, Telma Pelizer (2008) Nutrient Availability in the Soil and Its Absorption, Transport, and Redistribution in Vines, Communications in Soil Science and Plant Analysis, 39:9-10: 1507-1516.

Havlin J. L., D. H. Hardy, R. J. Gehl i S. E. Spayd (2012) Survey of Nutrient Status in Vitis vinifera Grapes in North Carolina, Communications in Soil Science and Plant Analysis, 43:1-2, 299-314

Licul R., Premužić D. (1985) Praktično vinogradarstvo i podrumarstvo. Zagreb: Nakladni zavod Znanje

Marschner, H. (1995) Function of mineral nutrients: micronutrient; Mineral nutrition of higher plants, 2nd ed., 313-404.

California, USA: Academic Press Inc

Miklaužić Lj. (1989) Ishrana vinove loze i gnojidba vinograda, Gospodarski list-Agrotehničar, Zagreb

Mirošević N. (1993) Vinogradarstvo, Zagreb: Nakladni zavod Globus

Mengel, K., E. A. Kirkby, H. Kosegarten, T. Appel (2001) Principles of plant nutrition. 5th ed. The Netherlands: Kluwer Academic Liming with Calcipril, Omya Corporate Brochures, 2020

Perica, S., P. H. Brown, J. H. Connell, i H. Hu (2002) Olive response to foliar boron application. Acta Horticulturae 586:381-83

Robinson, J. B. (2000) The mineral nutrition of wine grapes in Australia. Acta Horticulture, 512: 17-22

Romheld, V., H. Marschner (1991) Function of micronutrients in plants. In Micronutrients in agriculture, ed. by J. J. Mortvedt, F. R. Cox, L. M. Shuman, R. M. Welch, 2nd ed., 297-328. Madison, Wisconsin: SSSA

Rodrigues, M. Â., I. Q. Ferreira, A. M. Claro, M. Arrobas (2012) Fertilizer recommendations for olive based upon nutri-

ents removed in crop and pruning. Scientia Horticulturae Amsterdam 142:205-11

Strikić F., Gugić J. Klepo T (2012) Stanje hrvatskog maslinarstva, Glasilo biljne zaštite 12(4):271-276

Sumner M.E. (2000) Handbook of Soil science, New York, SAD: CRC Press

Valli R. (2001) Arboricoltura generale e speciale, Edagricole, Italija

Sharma, K. N. Deb, D. L. (1988) Effect of organic manuring on zinc diff in soils of varying texture. Journal of the Indian Society of Soil Science, 36: 219-224

Škorić A. (1982) Priručnik za pedološka istraživanja, Zagreb: Fakultet poljoprivrednih znanosti

Tagliavini, M., A. D. Rombolá (2001) Iron defi y and chlorosis in orchard and vineyard ecosystems. European Journal of Agronomy 15:71-92

Therios, I. N. (2009) Olives. Crop production science in horticulture. 18. Wallingford, UK: CAB International.

Tisdale, S. L., W. L. Nelson, J. D. Beaton (1985) Soil fertility and fertilizers. New York: Macmillan

Turan H.S., E. Aydogdu, T. Pekcan, H. Colakoglu (2013) Microelement Status and Soil and Plant Relationships of Olive Groves in West Anatolia Region of Turkey, Communications in Soil Science and Plant Analysis, 44:1-4, 80-88

Winkler, A.J., Cook, J.A., Kliewer, W.M., Lider, L.A. (1974) Soil for grapes. In General viticulture, Edited by: Winkler, A.J. 63-67. Berkeley, CA: University of California Press

\title{
Autumn fertilization of grapes and olives
}

\begin{abstract}
Grapes and olives are the two most important fruit crops in agricultural production in Croatia. About 40,000 producers are engaged in the cultivation of vines, while 20,000 producers are engaged in the cultivation of olives. As these are perennial woody crops, autumn fertilization is very important to supply the vines and olives with the necessary nutrients for growth and development in the next vegetation cycle. An important prerequisite for proper fertilizer application is soil analysis to determine soil fertility and compile a proper fertilization plan. There are different types and formulations of fertilizers on the market for autumn fertilization of vines and olives.

Key words: Grapes, olives, autumn fertilization, phosphorus, potassium, organic matter
\end{abstract}

